\title{
Role of dual phase MDCT in renal cancer - beyond the renal mass
}

\author{
D Santosh*, D Fleming, M Robinson \\ From International Cancer Imaging Society (ICIS) 14th Annual Teaching Course \\ Heidelberg, Germany. 9-11 October 2014
}

\begin{abstract}
Aim
To illustrate the anatomy of renal vasculature and its variants on cross-sectional imaging.

To highlight the benefits of obtaining images in both arterial and venous phase in staging and follow-up of renal cancer.
\end{abstract}

\section{Content}

It is common practice to perform dual phase computed tomography $(\mathrm{CT})$ in preliminary staging and subsequent follow-up of renal cancer patients in some institutions across the United Kingdom. We provide the best examples from our institution (2010-2013) with illustrations and the clinical relevance for the conditions stated below.

\section{Arterial phase}

We discuss the normal anatomy and variants of the renal artery including early division of artery, accessory artery and double renal artery. In addition, usual and uncommon sites (e.g. muscle, small bowel, pancreas) of hypervascular metastasis in primary renal cancer patients will be illustrated.

\section{Portal-venous phase}

We will highlight the normal anatomy and variants of the renal vein (e.g. aberrant, accessory renal veins) and associated tumour infiltration in unexpected veins (e.g. portal vein, gonadal vein) and solid organ metastasis.

\section{Conclusion}

The renal vasculature is frequently visualised on imaging but often overlooked. This exhibit will provide radiology trainee's an insight into the anatomical variants and its relevance in management of primary renal cancer. It reminds them of the common and uncommon metastasise

\footnotetext{
* Correspondence: divyasantosh@gmail.com
}

University Hospital Of Wales, Royal Gwent Hospital, Newport, UK and tumour infiltration seen in renal cancer, thus affecting the outcome.

Published: 9 October 2014

doi:10.1186/1470-7330-14-S1-P41

Cite this article as: Santosh et al:: Role of dual phase MDCT in renal cancer - beyond the renal mass. Cancer Imaging 2014 14(Suppl 1):P41.
Submit your next manuscript to BioMed Central and take full advantage of:

- Convenient online submission

- Thorough peer review

- No space constraints or color figure charges

- Immediate publication on acceptance

- Inclusion in PubMed, CAS, Scopus and Google Scholar

- Research which is freely available for redistribution
() Biomed Central

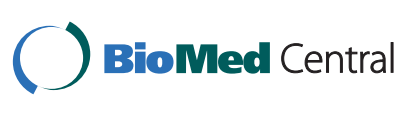

